\title{
The Phenomenology of Contagion
}

\author{
Annu Dahiya
}

Received: 15 May 2020 / Accepted: 17 July 2020

(C) Journal of Bioethical Inquiry Pty Ltd. 2020

\begin{abstract}
The lived experience of COVID-19 forcibly returns us to our bodies. This essay uses this (for most, sudden) return to embodiment to consider how our senses, as well as our "sense" of space, have been reoriented by this pandemic. It turns to certain strands within feminist philosophy that have questioned the privileged place vision has been accorded in the history of Western thought, as well as to mid-twentieth century phenomenologist Maurice Merleau-Ponty's aim to rediscover the world of perception by philosophically centring the body, as touchstones to put forth a phenomenology of contagion. Contagion makes us confront our phenomenological and embodied experience of tactility. This focus on tactility undermines the philosophical hierarchy of the senses that accords sight as the most "noble" of the senses in Western canonical thought. While COVID-19 results in us rediscovering our bodies through touch in a moment of fear and panic, this essay considers how this rediscovery may be harnessed for different, possibly more just, futures.
\end{abstract}

\footnotetext{
A. Dahiya $(\bowtie)$

Duke University, Durham, North Carolina, USA

e-mail: annu.dahiya@duke.edu
}

Keywords COVID- $19 \cdot$ Contagion $\cdot$ Feminist philosophy $\cdot$ Lived experience $\cdot$ Phenomenology $\cdot$ Touch

Contagion, $\mathrm{n}$.

Contāgiōn-em: A touching, contact, contagion.

Con- together + tangěre to touch.

-Oxford English Dictionary (2020)

\section{Contagion: A Topology of Touch}

During the month of March 2020, Steven Soderbergh's Contagion (2011) - a nine-year-old film-began to top charts on various on-demand streaming services, including WarnerBros, Amazon Prime Video, and iTunes (Sperling 2020). This spike in viewing, in turn, generated articles assessing the scientific accuracy of MEV-1, a fictional recombinant paramyxovirus of pig and bat RNA genomes that causes twenty-six million 
across the globe (Jaber 2020; Kitz 2020). ${ }^{1}$ In their analysis of Contagion, Dixon and Jones argue that the film offers us the philosophical tools to theorize space through touch, or "a tactile topology" (Dixon and Jones 2015, 223). Soderbergh centres tactility to convey the threat of contagion. In the film's first four minutes, the tactile topologies of infected bodies take centre stage. The first scene is a black screen that is permeated with a wet cough in a public place as we hear people speaking in the distance.

We shortly learn who is coughing: Gwyneth Paltrow, sitting at a bar in a Chicago airport, enjoying a beer and grazing from a bowl of communal nuts. She already looks unwell, her skin pale and clammy, and her nose slightly red. After ending a phone call with an old flame she had a sexual liaison with just a few hours ago, she hands the bartender her card to pay for her drink. This cues the film's soundtrack, ushering in a high-pitched suspense-inducing siren. As soon as the bartender swipes Paltrow's card and uses the touchscreen to finalize her order, a fast-paced electronic score begins,

\footnotetext{
${ }^{1}$ The aspect of the film that some scientific authorities argue is most accurate is its ending, which presents to the viewer the precise origin story of the pandemic, pinpointing exactly how the MEV-1 jumped species from a bat to eventually human in a way that is not possible for epidemiologists to do as they lack the disembodied, all-knowing cinematic gaze able to disclose this information. Indeed, much of the film's plot centres on World Health Organization epidemiologists painting the general landscape of where the spread of infection first emerged. They locate the beginning of the spread to a casino in Macau but are unable to determine the exact sequential events about when and how this originally bat virus crossed over to the human species. In the last scene of the film, a fast-pitched electronic score starts as we witness, in the dead of night, a bulldozer with the logo "AIMM Alderson" knocking down trees in a forest somewhere in rural China, displacing bats living within those trees. AIMM Alderson, incidentally enough, is the employer of Gwyneth Paltrow, who is the patient zero of the film. The AIMM-created deforestation results in a particular bat losing its home and flying far away, eventually finding its way into an industrial pig farm. Hanging upside down in the steel laden facility, the bat drops a piece of banana it's eating, which a small piglet subsequently ingests. This scene cuts to the same piglet chosen for slaughter by some farmers, and it is roughly moved from the industrial farm to the trunk of a truck in a wire cage. We next see the dead piglet, not yet butchered, resting on a countertop of a restaurant. A chef is in the process of seasoning its mouth with salts and spices when he is asked by another worker to meet business executives in the casino, wiping his hands on his apron rather than washing them with soap and water. The film ends with the chef smiling and holding hands with Paltrow while they pose for a picture to commemorate the moment, which induces the same high-pitched suspense-inducing siren that we hear in the film's opening scene. Paltrow then subsequently spreads the MEV-1 to others in the casino, beginning to feel ill herself twenty-four hours later, and dying the next day.
}

mirroring the tempo of MEV quickly spreading across the globe as the scene cuts from Kowloon, Hong Kong, to London and Minneapolis, all in the first four minutes of the film. Each time a city is introduced, its population size is noted, which represents the number of bodies at risk of being infected in each metropolitan hub. As people visibly become ill and swiftly die from MEV-1, the camera makes it a point to linger on what these sick bodies touch: public transportation surfaces, elevator buttons, office work documents, taxis and cars, bus and airplane bathroom handles, and drinking glasses, as well as who they are physically near and touch: their loved ones, neighbors in a cramped elevator, fellow public transit passengers, and coworkers. MEV1's movements in Contagion call attention to tactility and the relationality of touch as it traverses species, populations, and surfaces, cutting across the boundaries of nation-states. In our contemporary globalized world, the movement of viruses is inevitable. Their movement cannot be completely controlled, though it can be massively contained. Contagion reminds us that the global is local just as much as the local is global, and it makes the local global through its cinematic focus on touch. In doing so, the film visually brings attention to tactile topologies of contagion. This attention to tactility returns us to our bodies.

\section{COVID-19: A Forceful Rediscovery of the Body}

The threat of contagion returns us to our body, but it does so in a fear-stricken sense. Our corporeality becomes forcibly evident to us through fear and prohibition: do not touch your mouth, nose, or eyes; distance yourself from others; be mindful of and be sure to disinfect the surfaces you touch; sanitize and thoroughly wash your hands for at least twenty seconds (Marder 2020). This essay considers how our current lived experience involuntarily reorients our conceptual relation and embodied experience to touch. This pandemic challenges our lived experience of our bodies and senses, which provides us with the conditions to examine the philosophies that subtend how we understand, and perhaps order and even privilege, our senses.

As the many conceptual metaphors between vision and knowledge make clear (Lakoff and Johnson 1980, 48; Jay 1993, 1-2), vision has been intimately linked to knowledge in Western philosophy (Keller and Grontkowski 1983). This intertwining of vision and knowledge has resulted in the crowing of vision as the 
most "noble" of the senses (Jay 1993, 21; Jonas 2001; Keller and Grontkowski 1983, 208-215). As Vesey argues, "we can imagine a disembodied mind having visual experiences but not having tactile ones. Sight does not require our being part of the material world in the way in which feeling by touching does" $(1967,252)$. Touch, both philosophically and bodily, resists the disembodiment that vision invites - something that has been argued within feminist philosophy (Keller and Grontkowski 1983; Vasseleu 1998; Irigaray 2011). The privileging and favouring of the mind's eye over the body's eye allows for all the body of the knowing subject to become "neutral" and disappear (Keller and Grontkoswki 1983, 209).

COVID-19 is viscerally experienced. ${ }^{2}$ It makes some of us profusely sweat while we experience a constant, persisting sense of panic (Musser 2020). ${ }^{3}$ Our awareness of our corporeality during this pandemic positions us to engage with phenomenology. A philosophical movement that began in the late nineteenth century, phenomenology concerns the study of "structures of consciousness as experienced from the first-person point of view" (Woodruff 2018). The threat of COVID-19 can be thought through a phenomenological analysis that grounds itself in the locus of the body. It is in this regard that Maurice Merleau-Ponty (1908-1961), one of the most radical philosophers of phenomenology, provides us with the tools to process our lived experience of COVID-19. In his development and transformation of phenomenology, Merleau-Ponty posits the body as central to all conscious experience (Vasseleu 1998, 22).

Phenomenology, as Merleau-Ponty develops it, tells us nothing new. This is because, for him, phenomenology must undertake a philosophical rediscovering. Phenomenology's task is "to rediscover the world in which we live, yet which we are always prone to forget" (Merleau-Ponty 2004, 39). This is nothing other than the

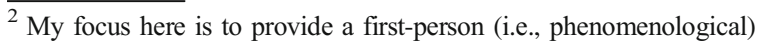
account of contagion. As such, I do not have space here to address how this pandemic is an effect of ecological destruction. On this, see Honigsbaum 2019.

${ }^{3}$ This panic is heightened in communities who are not in control of the spaces their bodies occupy. The threat of COVID-19 is bound to materialize into disastrous effects in communities that cannot maintain social distancing - whether it be low-income (often brown and black) families who live in tight quarters, migrants entrapped in detention centres, those that are incarcerated, and those who must take public transportation because they are "essential" workers and therefore need to continue to physically work outside the spaces of their homes to economically survive, as opposed to white-collar workers who can teleconference from home (Serwer 2020).
}

world of perception, and this rediscovery hinges on, is made possible by, the body. Merleau-Ponty's "aim is to realign our philosophical understanding of perception and the body with things we are already familiar with before we begin to reflect and theorize" (Carmon 2012, $\mathrm{xV}$-Xvi). To declare the primacy of perception is to assert that we perceive before we think. This is a direct challenging of Descartes, for whom mind is ontologically prior to the senses. For Merleau-Ponty, that perception is the condition of possibility for thought, as it is the primordial background that must first exist for thought to then emerge as its foreground (xii-xiii). MerleauPonty argues that our senses "cover their tracks as they organise our experience," so that we forget and become wholly unaware of "the role of the senses in organising experience and 'constituting' the physical world" (Merleau-Ponty 2004, 13).

While for Merleau-Ponty modern art and philosophy "allow us to rediscover the world in which we live, yet which we are always prone to forget," the threat of contagion - in other words, our lived experience of COVID-19-also, but much more forcibly, engenders a rediscovering of the world of perception (MerleauPonty 2004, 39). We're now acutely attuned to how our bodies inhabit space, what touches our body, and what our bodies touch in a way that we weren't before.

\section{The Un-Eliminability of Contagion, the Relationality} of Touch

Touch itself, like contagion in its most ontological sense, is neither inherently positive nor negative (Dahiya 2018). Evolutionary biologists and virologists argue that contagion is an inevitable effect of living replication systems (Iranzo et al. 2016). Viruses are the most abundant living entities on the earth, populating the earth several orders of magnitude greater than other microscopic actors such as bacteria (Zimmer 2020). This in itself signals the need to rethink space and touch in relation to viral contagion. Ontologically, contagion is coextensive with all biological systems. If contagion is a ubiquitous force and feature within the virosphere in which we exist, reorienting ourselves conceptually and bodily to touch subverts the privileged position the sense of vision and metaphors of light have been given in dominant Western models of thought.

The biomedical concept of immunity was coined around the idea of "self-defense" in the late nineteenth century by Elie Metchnikoff (1845-1916). That 
contagion is coextensive with living systems, combined with our inescapable immersion in a viral milieu, calls into question whether our understanding of immunity as a body's self-defense is an apt response to the phenomenology of contagion, both during and after this pandemic. Instead of immunity and/as self-defense, an orientation to our philosophical understanding and visceral experience of our body, its corporeality, and its relations with and to others would perhaps be better captured by the idea of community, "since community foregrounds the co-constitutive dynamics of living" (Cohen 2003, 159). ${ }^{4}$ COVID-19 is both a virus and a relation, one that calls for us to "center care and the webs of social relations, the historical relation of oppression carried in bodies (Shotwell 2020). We should use this return to our bodies to remember that touch is always relational: it puts us in community with our own corporeality, as well as in physical and social relations with others.

What world of perception are we rediscovering living through this pandemic? Touch is the most primordial of the senses, it lines all the other senses, including vision, and therefore is ineliminable (Irigaray 1993, 162; 2011, 137; Vasseleu 1998). That is why we scrub and lather for at least twenty seconds and physically distance our bodies from others. During this time, we are attuned to take up MerleauPonty's phenomenological project, coupled with feminist philosophy's critique of the privileging of vision in our thought and our lived experience. We confront and are confronted by our materiality and vulnerability when our lives are threatened through touch. We become aware of touch and tactility when we should fear all contact. Touch is inevitable; it is the condition of possibility for all of the other senses and perception in its most fundamental sense. Through our bodies rediscovering perception, Merleau-Ponty believed philosophy could begin anew. What, if anything, will the tactile phenomenology of contagion reimagine for us?

Acknowledgments Thank you to Maninder Singh Arneja, Kimberley Dimitriadis, Elizabeth Grosz, MD Murtagh, and the Journal

\footnotetext{
$\overline{{ }^{4} \text { That contagion }}$ is coextensive with living systems and our inescapable immersion in a viral milieu challenges, or at the very least momentarily destabilizes, the meaning of immunity and health. Indeed, some virologists argue that our immune systems themselves are evolutionary inventions of viruses (see Villarreal 2011).
}

of Bioethical Inquiry editorial team for thoughtful feedback throughout the process of writing this piece. This essay was written at a time when my mother, a nurse, became critically ill with COVID-19 for several weeks. She has since recovered. I dedicate this paper to those who have lost loved ones to COVID-19.

\section{References}

Carmon, T. 2012. Foreword to The phenomenology of perception, by Maurice Merleau-Ponty, vii-xvi. Translated by Donald A. Landes. New York and London: Routledge.

Cohen, E. 2003. Metaphorical immunity: A case of biomedical fiction. Literature and Medicine 22(2): 140-163.

Dahiya, A. 2018. Before the cell, there was virus: Rethinking the concept of parasite and contagion through contemporary research in evolutionary virology. In Transforming contagion: Anxieties, modalities, possibilities, edited by Breanne Fahs, Annika Mann, Eric Swank, and Sarah Stage, 42-55. New Brunswick, NJ: Rutgers University Press.

Dixon, D.P., and J.P. Jones III. 2015. The tactile topologies of Contagion. Transactions of the Institute of British Geographers 40: 223-234.

Honigsbaum, M. 2019. The Pandemic century: One hundred years of panic, hysteria, and hubris. New York: W.W. Norton \& Company.

Iranzo, J., P. Puigbò, A.E. Lobkovsky, Y.I. Wolf, and E.V. Koonin. 2016. Inevitability of genetic parasites. Genome Biology and Evolution 8(9): 2856-2869.

Irigaray, L. 1993. An ethics of sexual difference. Translated by C. Burke and G.C. Gill. Ithaca, New York: Cornell University Press.

Irigaray, L. 2011. Perhaps cultivating touch can still save us. SubStance 40(3): 130-140.

Jabr, F. 2020. How realistic is Contagion? The movie doesn't skimp on science. New Scientist, April 6. https://www. newscientist.com/article/2239913-how-realistic-iscontagion-the-movie-doesnt-skimp-on-science/\#ixzz6LVt0 dVDP. Accessed May 1, 2020.

Jay, M. 1993. Downcast eyes: The denigration of vision in twentieth-century French thought. Berkeley: University of California Press.

Jonas, H. 2001. The nobility of sight: A study in the phenomenology of the senses. In The phenomenon of life: Toward a philosophical biology, by H. Jonas, 135-151. Evanston, IL: Northwestern University Press.

Keller, E.F., and C.R. Grontkowski. 1983. The mind's eye. In Discovering reality: Feminist perspectives on epistemology, metaphysics, methodology, and philosophy of science, edited by S. Harding and M.B. Hintikka, 207-224. New York: Kluwet Academic Publishers.

Kritz, F. 2020. Fact-checking "Contagion"-In wake of coronavirus, the 2011 movie is trending. National Public Radio, F e b r u a r 16. h t t p s : / / w w w . n p r. org/sections/goatsandsoda/2020/02/16/802704825/factchecking-contagion-in-wake-of-coronavirus-the-2011movie-is-trending. Accessed March 20, 2020. 
Marder, M. 2020. Contagion: Before and beyond COVID-19. Los Angeles Review of Books, March 19. https://lareviewofbooks. org/short-takes/contagion-before-beyond-covid-19/. Accessed May 1, 2020.

Merleau-Ponty, M. 2004. The world of perception. Translated by Oliver Davis. London and New York: Routledge.

Musser, A. 2020. Sweat. Social Text Online, April 27.https://socialtextjournal.org/periscope_article/sweat. Accessed May 1, 2020.

Oxford English Dictionary. 2020. Entry for "contagion." Oxford University Press. https://www.oed.com/. Accessed May 9, 2020.

Serwer, A. 2020. The coronavirus was an emergency until Trump found out who was dying. The Atlantic, May 8. https://www. theatlantic.com/ideas/archive/2020/05/americas-racialcontract-showing/611389/. Accessed May 8, 2020.

Shotwell, A. 2020. The virus is a relation. Upping the Anti, May 5. https://uppingtheanti.org/blog/entry/the-virus-is-a-relation. Accessed May 7, 2020.

Soderbergh, S., dir. 2011. Contagion. Burbank, CA: Warner Bros, DVD.

Sperling, N. 2020. “Contagion,” Steven Soderbergh's 2011 thriller, is climbing up the charts. The New York Times, March 4. https://www.nytimes.com/2020/03/04 /business/media/coronavirus-contagion-movie.html. Accessed March 10, 2020.

Vasseleu, C. 1998. Textures of light: Vision and touch in Irigaray, Levinas, and Merleau-Ponty. New York and London: Routledge.

Vesey, G.N.A. 1967. Vision. In The Encyclopedia of philosophy, 252-253. New York: Collier Macmillan.

Villarreal, L.P. 2011. Viral ancestors of antiviral systems. Viruses 3(10): 1933-1958.

Woodruff, D.S. 2018. Phenomenology. In The Stanford encyclopedia of philosophy, edited by E. N. Zalta. https://plato. stanford.edu/archives/sum2018/entries/phenomenology/. Accessed May 1, 2020.

Zimmer, C. 2020. Welcome to the virosphere. The New York Times, March 24. https:/www.nytimes.com/2020/03/24 /science/viruses-coranavirus-biology.html. Accessed 1 May 2020.

Publisher's note Springer Nature remains neutral with regard to jurisdictional claims in published maps and institutional affiliations. 